\title{
Street Vendor: The Study of Heredity Job and Social Behaviour
}

\author{
R. Purnama \\ Universitas Pendidikan Indonesia \\ Bandung, INDONESIA \\ ridwan_poer@yahoo.com
}

\begin{abstract}
An urban Bandung in West Java that has a dense population recorded in 2014 the population of the Bandung City totaled 2,483,977 people, the impact of these conditions were increasingly heavy burden of the city facing a very complex and complicated with a variety of problems such as pollution, population density, urbanization, urban transport, and complex problems are not well-organized and the city as a result of uncontrolled growth of street vendors .this research is focused on the presence of street vendors which is a business group structure bottom in the levels of world trade. The existence of street vendors is actually not a problem when they follow the norms and provisions of applicable law, but reality shows, the informal sector of the city has been denying a number of norms and regulations applicable law. In the juridical-sociological study of these conditions shows that the growth and development of street vendors are not always followed by the arrangement and law enforcement that gave birth to deviant behavior (deviation). Therefore, this research is intended to describe and analyze the influence of the attitude of street vendors to law enforcement officials and motivation vendors against deviant behavior of street vendors in the city of Bandung. While the methods used in this research are an explanatory survey emphasis on efforts to obtain information about a phenomenon at the time of the research conducted so as to get the findings of the attitude of street vendors, work motivation to the damned law enforcement affect the deviant behavior of street vendors in the form of violation of norms or regulations in Bandung.
\end{abstract}

Keywords : Socio-juridical, Deviasi, Street Vendors

\section{THE EXISTENCE AND THE PROBLEM OF STREET VENDORS IN BANDUNG}

Bandung is a region in the former ancient lake basin area, now has very much changed, from a village called Negorij Bandoeng which has a population of only 6000 people and an area of 4000 hectares (Kunto, 1984:892). Has now become a large city with a population density of approximately 16394 inhabitants/square kilometers, with a total population in the city of Bandung, reaching $2,748,733$. A population density figures far above the ideal ratio is required.

The impact of these conditions, Bandung became a very solid growing bolder weight face the burden of town and very complex and complicated by a variety of problems such as pollution, population density, urbanization, transportation, and the problem of crowded of the city due to not place well and uncontroling the growth of street vendors

The structure of the population of Bandung based on the kinds of livelihood demonstrate the diversity of non- agricultural livelihoods such as trade, the employee (personnel), transportation, and services. This is a logical consequence, that kind of livelihood such as the impact of the existence of the city of Bandung as a major city which has various functions such as an industrial city, tourism city, education city, town services and designations which demonstrates the function of Bandung itself.

Questioning the existence of Bandung with his functions, then the Bandung city cannot stand on its own without any connection with the countryside or the cities of the County as a buffer the necessities of life in the city. So, in line with the development of the city, the migration to Bandung city each year continues to increase. In fact, not only of cities, counties and rural areas close to Bandung alone do geographical mobility to Bandung city, but from other towns even from another province.

Those who commit to the geographic mobility of Bandung in order to find work (for a living), sometimes do not get the job as expected. This is due to lack of effort in the formal sector and the strict qualifications required in the sector led to a large majority of migrants attempting the informal sector of the city, adding to a long row of street vendors in Bandung, which had previously been filled by those from diverse ethnic, mainly from the area Sumatra, who did come to the city of Bandung with the aim to become street vendors.

Street vendors is the structure of the lowest business group in the hierarchy of world trade, Indonesia citizens as anyone can easily become street vendors because it does not require formal requirements-juridical, so over the years the numbers are ever increasing in Bandung city.

The high percentage of growth of street vendors will be caused by the lack of job opportunities. If we examine far behind it is not detached from the impact caused by the prolonged economic crisis afflicting our country, joints that cripples our economy, which in turn gave rise to a new generation with unemployment status, whether skilled or not. Logically the consequences, because people must continue to live then they have the motivation with constantly strives to meet the needs of his life. The motivation or a strong urge to live and raise a family, it's a thing that inevitably triggers, whoever the person is, be striving mightily obtain any activities to earn money. And the alternative is given, with all its convenience, through efforts in the informal sector that is to become street vendors. In line with that, Arif Hidayat (2009), declares that:

The imbalance between the amount of available labor and employment opportunities spawned new initiatives for some members of the community to preserve his life. One 
of the road taken is to become street vendors, although it is not the will that they should do

\section{THE PROBLEMS OF LAW ENFORCEMENT STREET VENDORS IN BANDUNG}

The existence of street vendors is actually not a problem if they follow the norms and legal provisions in force, for making a living by trading is the right of every citizen of Indonesia. Our state constitution explicitly states that every citizen has the right to earn a decent living. But the unfortunate thing of the vendors, is the low awareness of the law they have. It should be as good citizens, they should be able to comply with the provisions in force, to respect the rights of other citizens, and can appreciate the presence of enforcement officers in carrying out their duties. As expressed by Head of Bappeda Bandung that:

What can we see and feel, the informal sector of the city (street vendors) has denied a number of norms and the rule of law. So, the basic pattern of the development of the city of Bandung which confirms that the informal sector the town can indeed be a buffer and a provider of jobs, but the reality of the pointed out the presence of street vendors turned out to have been disturbing the public order, cleanliness and beauty of the city.

In a study of socio-juridical conditions will be portrayed if the reality on the ground where street vendors in accordance with the applicable provisions that will create the city that genah, merenah, and tumaninah, as well as clean, green and flowering in accordance with the motto of Bandung city as the City of Champions. However, reality shows that, growth and development of the hawkers always not followed by the arrangement and the rule of law, hence the birth of deviant behavior from them, that is behavior that does not comply with the social norms of a social group or behavior that violates the provisions instituted, which in turn give rise to a variety of multi-dimensional problems in the social life at Bandung.

The social functions of public facilities have been changed into a place of business, trade or sale of land commonly referred to is the same reality that often occurs either performed between street vendors with a plurality of apparatus, occupies a new and or sellers holding out for is not expelled by paying levies ' illegal ' is something that often happens once. Social functions which should be allocated in one area, gradually began to shift into a new land seller, who did not elaborate. Consequently, the community should utilize the area, now lost and only a hope to return it to a position proportionally.

Legally, the concept and the integrated model that governs the development of street vendors stipulated in Decree Mayor Bandung No. 624 of 1999 concerning regulation of street vendors in the Municipality of Bandung, which is implemented with the establishment of the Regulation and Development of Street Vendors in Bandung set forth in the decree of the Mayor Bandung No. 625 of 1999, which was basically in order to empower vendors who then in turn be a formal traders, to have a place to do business representative.

The good intentions of the Government of Bandung even looks as limited formal policy, if you see the reality on the ground, whereas ethnic Sundanese egalitarian attitude is positive entry point in support of the Government of Bandung in implementing policies on the pavement. The approach that has been done by giving priority to 'power' and 'repressive' received strong resistance from the vendors, and this is certainly going to create new problems for the stability of the city.

The problem of street vendors in $t$ Bandung never seem to finish. The long history of handling, controlling and coaching vendors, starting with the publication of Decree of the Mayor of the municipality Level II Bandung No. 624 of 1999 concerning regulation of street vendors in the Municipality of Bandung, which is implemented with the establishment of the Regulation and Development of Street Vendors in Bandung Bandung Mayor stipulated in Decree No. 625 of 1999. Then the mayor of Bandung issued Decree No. 511.23 / Kep. 1322-Huk / 2001 on the Prohibition of Activities Street Vendor in Seven Points, however, the effectiveness of law enforcement of street vendors in the city of Bandung never succeeded. In 2005, the Government of Bandung again tried to organize street vendors through Bandung Regional Regulation No. 11 Year 2005 on the Implementation Order, Cleanliness and Beauty (In Indonesia Called K3), but returned unsuccessful. And lastly, to further strengthen the legal basis in the structuring and formation of hawkers, republished Bandung Regional Regulation No. 4 Year 2011 on Management and Development Lima Street vendors in Bandung. However, both the local regulation cannot be a powerful moment to regulate street vendors.

In the context of the handling of street vendors in the city of Bandung, interesting to be listened to what is expressed by the Deputy Mayor of Bandung (Bandung, Diskominfo, 2011):

The handling of street vendors should be placed as the subject of dignity, through the approach and dialogue not only repressive nature activities, since its existence is one of the city's economy wheel drive machine, so it can be styled properly.

From the statements we might conclude that the approach must be made in the law for enforcement of the street vendors do not exclusively repressive in nature alone, but needed another approach. According to the author, see saving social complexity in the law enforcement issues for street vendors, then his law enforcement needs to be carried out through two approaches, namely the juridical and non-juridical. So in this context meant that law enforcement must be construed broadly where the rule of law includes not only the juridical activities in the form of death with (repressive) of the apparatus but also the activities of non-juridical form of education (pre-emtif) and prevention (preventative).

\section{THE STUDY OF JURIDICAL-SOCIOLOGICAL BEHAVIOR DEVIATES STREET VENDORS IN BANDUNG.}

Sociologically, that the social reality of the existence of street vendors as a social group that is difficult to adjust to his actions always violate social norms and regulations in effect, is a social phenomenon that is abnormal that needs to be balanced with social control and law so that its activities do not cause unrest social. in analyzing this issue Malinowski (in Koentjaraningrat, 1987: 167) argues that:

In modern society, civic conduct guarded among others by a system of coercive social control that is legal 
and prevail, the law was supported by a system of power tools (police, courts and so on are organized by country).

Actions or behavior contrary to the norms and / applicable law whenever the greater enforcement by enforcement officers against street vendors indecisive and inconsistent. Though the socio-juridical legal norms to sanction physical, as opposed to social norms more (folkways, mores, norms, and custom) that are psychics, has the power to impose penalties which have a deterrent effect for those who do not comply or violate

social norm is a or the size or number of views on a behavior which is generally accepted and agreed upon by the citizens of a society. Norma gave lines of reference about what behavior and how appropriate and should be done in the face of a certain social circumstances. Thus the social norm is a social measure which determines what should be done, what must-have-believed-desired by a person as a member of society. Furthermore, Judistira Garna K. (1996: 170) reveals that:

If a norm that is normative is putting pressure will the fact that the conduct it to adjust and comply with the expectations and desires of the community at large. Those who don't comply or conflicting with social norms will be deemed aberrant (deviance).

Talking about how the law or regulations are not enforced regardless of the components of the law enforcement system. Lili Rasjidi (1993: 114) argues that: The system components application of the law includes three main components, namely component of applicable laws, the institutions that will implement it, and the personnel of the institution these organizers generally include institutions of administrative and judicial institutions, such as police, prosecutors' judges, and various institutions that serve administratively enforce the law in the executive ranks.

The fact is that application of the law organizing the legal relationship settings for each Union law in a community of law. This setting includes aspects of prevention of violation of the law, and dispute resolution law, including the restoration of the conditions for any damage resulting from the breach of it (Rasjidi, 1993:113). The third major component of the application of the law (legal, institutional, and personnel) as expressed above, according to the save the author has an impact on the effectiveness of the law in force. A. Warlan (1989) posited things that influence the effectiveness of a rule of law is a law of its own conditions, including perceptions against its own regulation; the conditions of law enforcement; and cultural factors. L. Friedman in Legal System suggests that there are three things that influence the effectiveness of a rule of law that is of sanctions (against the perception rule/sanction); social environment; and internal values. Whereas Soerjono Soekanto (1982) mentioned that the effectiveness of a rule effected by the level of awareness of the law society.

The effectiveness of law enforcement in the community can be seen from how the effects of regulation / law is against society. The essence of the law and or regulatory influence on society is people's behavior in accordance with the laws and / regulations. So it can be said that the effectiveness of the rule of law can be seen from the extent to which the occurrence of deviations between the regulations in effect (das solen) that people's behavior is expected, with the realities that occur (das sein) the behavior of everyday people.

Legally -sociologist, with reference to the opinions mentioned above, it can be argued that in the application and enforcement of law in society, one of the most instrumental component is personnel, law enforcement, and law enforcement agencies in applying legal sanctions. It happened because law as a social fact in society requires mediators through personnel and / law enforcement personnel as bridge the social relations between social institutions (read: political) with members of the public. To borrow a term Malinowski, that law enforcement officials is a power tool to support law enforcement.

the function of the social structure, which is a series of complex of social relations that is tangible in a society, influenced by the extent to which the institution or institutions established the role and involvement of these institutions is influenced by the extent of the role of the personnel or law enforcement personnel in these institutions to function.

Structurally, Bandung City Government through the Development Team Street vendors his is a social institution that has a function to solve community problems, particularly social problems associated with deviant behavior by street vendors in the city of Bandung.

The behavior deviates according Judistira Garna K. (1996: 156) is: "any behavior that does not comply with the social norms of a social group, or community, or behavior that violates the provisions instituted, the conditions agreed upon legitimate within a social system." the theory that talks about Merton's theory of deviant behavior is based on the concept of Anomie. Deviation or anomie is the result of circumstances that are not in harmony between the objectives of cultural and institutional means available to achieve those goals. (Robert K. Merton, in Purnama, 2005: 24) According to Merton, anomie will not show up as far as the public provide institutional means for achieving the cultural objectives. Furthermore, Merton argues that:

We experience is usually a situation of "conformity" where legitimate means are used to achieve the desired goals. But when the cultural objectives and institutional means are no longer aligned, then the result is anomie or non-conformity. (Margaret $m$. Poloma in full moon, 2005:34).

Deviations from the norms prevailing in society can be regarded as abnormal symptoms and it is a social problem (ameliorative) arising from the deficiencies in man or group of men which is based on economic factors, biological, bio-psychological and culture. So basically social problems concerning social values and morals; to the problems is a problem, because of concerns the code of conduct that is immoral, unlawful and destructive, and therefore to the problems of social would never be explored without consider measures of the community about what is considered good and what is considered bad (Robert A. Nisbet, in Soekanto, 1988: 369).

Conclusions about how law enforcement against the deviant behaviour of street vendors in the city of Bandungridis-sociological perspective of the juridical sociological-can be expressed as follows: 
1) by the sociological, the occurrence of irregularities (anomie) of the street vendors in the city of Bandung, is caused by the occurrence of contradiction (nonconformity) between cultural goals shared by street vendors, namely for a living, with the unavailability of the means to trade (structural)

2) Legally, the occurrence of irregularities the street vendors against the provisions of the regulations in force is inseparable from the weak law enforcement three main components, namely, the law applicable, components institutions that will implement it, and personnel from institutional providers is generally include administrative agencies and judicial institutions, such as police, prosecutors, judges and institutions that function organizes the law administratively in the executive ranks,

3) Based on the complexity of social problems that occur in law enforcement for the street vendors, then law enforcement needs to be carried out through two approaches, namely the juridical and non-juridical. So in this context meant that law enforcement must be construed broadly where the rule of law includes not only the juridical activities in the form of enforce (repressive) of apparatus/officers only, but also the activities of nonjuridical form of education (pre-emtif) and prevention (preventative).

4) Some things need to be considered within the framework of the rule of law is the implementation of the law in the theory of positive law which includes:

- Legal substance that various provisions / written rules exist;

- Legal Structure is concerning infrastructure / facilities and institutional / bureaucratic law;

- Culture Law that all factors that determine how the legal system gained its place.

5) In socio-juridical, the interaction between the officer / officers with vendors, will cause a conflict if both parties do not have awareness of law as good citizens who are able to respect any rights and obligations, and does not do communications to produce a form of ' cooperation 'between the two groups of citizens. In addition to the application of the rules or the law made it 'repressive' by the authorities would lead to resistance, so that in this context the conflict between officials / officers with street traders this result does not do application of the rules / law restitutif by the authorities so as not to produce some form of accommodation between the two social groups.

\section{REFERENCES}

[1] Apeldoorn, LJV, 1986, Pengantar Ilmu Hukum, Jakarta: Pradnya Paramita

[2] Arief, BN, 2001, Masalah Penegakan Hukum dan Kebijakan Penanggulangan Kejahatan, Bandung: PT Citra Aditya Bakti

[3] Blau, Peter M., Joan W. Moore, Sosiologi, dalam Bert F. Hoselitz (ed.), 1988, Panduan Dasar Ilmu-Ilmu Sosial, Jakarta : Rajawali Pers.

[4] Campbell, Tom, 1994, Tujuh Teori Sosial : Sketsa, Penilaian, Perbandingan, Yogyakarta : Kanisius

[5] Daldjoeni, N, 2001, Seluk Beluk Masyarakat Kota : Pusparagam Sosiologi Kota dan Ekologi Sosial, Bandung : PT Alumni
[6] Friedman, LM, 2001, American Law, An Introduction, Jakarta: PT Tata Nusa

[7] Garna, Judistira K, 2004, Ilmu-Ilmu Sosial : Dasar, Konsep, Posisi, Bandung : Program Pascasarjana Universitas Padjadjaran

[8] ...................., 1997, Pemikiran Modern Dan Ilmu Pengetahuan Sosial, Bandung : Primaco Akademika, CV.

[9] Gilbert, Alan dan Gugler Josep, 1996, Urbanisasi dan Kemiskinan di Dunia Ketiga, Terjemahan Anshori, Juanda, Yogyakarta : Tiara Wacana

[10] Kunto, Haryoto, 1986, Semerbak Harum di Bandung Raya, Bandung : PT. Granesia

[11] Kusumaatmadja, M, 1970, Fungsi dan Perkembangan Hukum dalam Pembangunan Nasional, Bandung: Fakultas Hukum Universitas Padjadjaran

[12] Mertokusumo, S, 1999, Kesadaran Hukum Masyarakat Yogyakarta: UGM Press

[13] Neuman, W.L, 2006, Social Research Methods, Qualitative and Quantitative Approach, USA: Pearson

[14] Poloma, Margaret M., 1994, Sosilogi Kontemporer, Jakarta : Rajawali Pers.

[15] Purnama, R, 2005, Kajian Sosiologis Pedagang Kaki Lima, Tesis, Bandung: Unpad

[16] Rahardjo, S, 2009, Penegakan Hukum Suatu Tinjauan Sosiologis, Yogyakarta: Genta Publishing

[17] Rasjidi, Lili., 2004, Hukum Sebagai Suatu Sistem, Bandung : PT. Remaja Rosda

[18] Riyanto, Astim, 2007, Kapita Selekta Hukum dalam Dinamika, Bandung: Yapemdo

[19] .............., 2007, Filsafat Hukum, Baandung: Yapemdo

[20] Soekanto, Soerjono, 2009, Pengantar Sosiologi Hukum, Jakarta : Rajawali Pers.

[21] Soekanto, S, 1993, Faktor-Faktor yang Mempengaruhi Penegakan Hukum, Jakarta : PT Raja Grafindo Persada

[22] Triyanto, 2011, Penguatan Penagakan Hukum Hak Kekayaan Intelektual, Disertasi, Bandung: Universitas Pendidikan Indonesia

[23] Warlan, Asep, 1989, Efektivitas Hukum dalam Pembinaan Disiplin Pegawai Negeri Sipil, Bandung : PT. Intergrafika 